\title{
LIBERALISMO E DEMOCRACIA - Apontamentos sobre a evolução histórica dos conceitos liberais de democracia*
}

\author{
Sidney Tanaka de Souza Matos
}

Mestrando em Ciência Política pela Universidade Estadual de Campinas.

O presente artigo tem por objetivo buscar as raízes históricas das concepções liberais de democracia - resultado da fusão do liberalismo com as teorias democráticas, no século XIX - e entender o panorama no qual se dá essa fusão e as formas tomadas por essas teorias no século $\mathrm{XX}$.

Palavras-chave: cidadania; democracia; Estado; liberalismo.

\section{INTRODUÇÃO}

$\Lambda$ problemática acerca do avanço da democracia no mundo atual tem alcançado grande destaque nos meios acadêmicos contemporâneos. Com efeito, o colapso do assim chamado socialismo real no leste europeu e o processo de redemocratização da América Latina nos anos 80 , após um período de generalização de regimes militares em todo o subcontinente, inseridos dentro de um outro processo mais amplo de mundialização do capitalismo que tende a modificar profundamente o atual perfil dos Estados nacionais, tem posto em questão, não só nessas regiões mas em todos os países, os limites e o próprio conceito de democracia.

O conceito de democracia não é, ademais, nem uno nem estático, tendo passado por um processo de constante reformulação ao longo da história do pensamento filosófico e político e sendo hoje substancialmente diferente do conceito original da Grécia clássica. Uma grande parcela dos estudos contemporâneos a esse respeito, entretanto, conceituam-na a partir das idéias provenientes das variações da ótica liberal de democracia baseada, grosso modo, nas formas de democracia representativa ancoradas na existência do sufrágio universal ${ }^{1}$ (embora nem todas as linhas do pensamento liberal considerem a existência do sufrágio universal indispensável ao processo democrático, como se verá adiante) que concentram sua análise em uma esfera política relativamente autônoma em relação à sociedade civil, o que pode, por vezes, levar a uma interpretação reducionista em que a democracia é identificada com um simples mercado eleitoral.

O presente artigo tem por objetivo desenvolver um exercício teórico que busca entender o processo de desenvolvimento dessas concepções liberais de democracia, resultado da fusão das teorias democráticas com o liberalismo, no século XIX - fusão esta ocorrida em meio às transformações que afetaram profundamente o modo de produção capitalista —, e sua posterior evolução no século XX.

\section{O DESENVOLVIMENTO DA CONCEPÇÃO LIBERAL DE DEMOCRACIA}

\section{Considerações iniciais}

As bases sobre as quais vão se estruturar as concepções liberais de democracia derivam de um processo mais amplo de modificação da idéia de homem e das relações entre indivíduo e sociedade e indivíduo e Estado. Com efeito, na organização política do mundo grego clássico há uma valorização do ser coletivo em relação ao individual em que o indivíduo é livre enquanto parte integrante da sociedade

\footnotetext{
* O texto é uma adaptação da monografia intitulada Reflexão teórica acerca da democracia: elementos para análise do autoritarismo no discurso do governo FHC, apresentada como trabalho de conclusão do curso de Especialização em Sociologia e Sociologia da Educação, da UEL, em abril de 1998, sob orientação da professora Maria José de Rezende.
} 
onde vive, participante da esfera política da polis concorrendo para seu fortalecimento.

Essa concepção levará mais tarde a uma autonomização do Estado frente ao indivíduo, claramente visível em Maquiavel, que, embora enfatize a importância da virtú na figura do príncipe e a autodeterminação das ações humanas, ${ }^{2}$ confere à conquista do poder do Estado e à sua estabilidade importância capital na condução do processo social; ou visível em Hobbes, onde, para escapar ao estado de natureza, caracterizado pelo estado de guerra permanente, os homens, através de um contrato, acordam as regras de convivência social e de subordinação a um Estado, em que o soberano é o responsável pela manutenção deste mesmo contrato e, consequientemente, pela manutenção da paz e defesa dos direitos de cada indivíduo. ${ }^{3}$ Há, dessa forma, uma desconsideração do papel da sociedade em relação ao Estado, que preenche todos os espaços na determinação e condução desta sociedade a partir de uma ação tutorial.

Já a idéia moderna de liberdade liga-se, como coloca SARTORI (1965), a uma noção de liberdade individual baseada em direitos pessoais; ou seja, o Estado deixa de ser o elemento absoluto a ser considerado na condução da sociedade. Passa a ser observado o papel dos indivíduos e sua relação com esse Estado e, ao se dar ênfase à defesa dos direitos pessoais, surge a necessidade de impor limites à sua ação. Essa concepção individualista surge, segundo o autor, com a difusão do cristianismo e é desenvolvida na Renascença e na Reforma religiosa, onde o zoon politikon perde espaço para o indivíduo. Essa ênfase dada ao indivíduo vai, mais tarde, com a ascensão da burguesia e, conseqüentemente, do pensamento liberal, reforçar as tendências críticas ao Estado autonomizado em relação ao indivíduo, levando ao desenvolvimento de uma concepção de democracia que contrapõe sociedade e Estado, e derivando daí uma desconfiança em relação ao Estado e uma defesa da necessidade de controle e limitação de seu poder pela sociedade composta de indivíduos; através de um conjunto de garantias institucionais e constitucionais; noção a qual TOURAINE (1996) denominou liberdade negativa, na medida em que deriva da limitação do poder do Estado como forma de garantir a autodeterminação individual.

Outras concepções vão, mais tarde, centrar sua atenção numa concepção instrumental de democracia onde esta é vista como um método de determinação e legitimação da liderança em que o papel da participação da população na determinação dos rumos a serem tomados pela sociedade é diminuído, como é claramente constatado na teoria desenvolvida por Schumpeter: "o método é aquele acordo institucional para se chegar a decisões políticas em que os indivíduos adquirem o poder de decisão através de uma luta competitiva pelos votos da população". (SCHUMPETER, 1984, p.336)

Essa ênfase ao controle dos limites do Estado ou à instrumentalização de regras de acesso ao poder resultará, ao longo do século XX, no desenvolvimento de teorias democráticas que, paradoxalmente a sua significação literal, levam a um esvaziamento do caráter de participação popular na política enquanto meio de garantir o "poder do povo" e, até mesmo, a uma preocupação quanto aos perigos dessa participação popular para os destinos da democracia.
O desenvolvimento das teorias democráticas dentro desse perfil é decorrência, segundo PATEMAN (1992), do aparecimento e sofisticação da sociologia política no século XX e da emergência dos Estados autoritários.

O desenvolvimento da sociologia política, inserido dentro de um ambiente de complexização da sociedade industrializada e dentro do desenvolvimento das formas de organização altamente burocratizadas que marcaram o final do século XIX e início do século XX, levando a um certo ceticismo por parte dos teóricos da época em relação à viabilidade dos ideais democráticos que vinham se desenvolvendo paralelamente à ascensão da ordem burguesa na sociedade, calcada em grande parte na defesa da igualdade e da liberdade individual e que na época, desempenharam seu papel no processo de desmantelamento da velha ordem feudal.

Já a emergência dos regimes totalitários trouxe a preocupação concernente aos destinos da democracia se permitida a participação em massa da população; preocupação esta baseada no grande apoio popular conquistado pelos regimes nazi-facistas em sua ascensão e pelos regimes totalitários no pós-guerra, conforme comenta PATEMAN (1992, p.11): "O colapso da República de Weimar, com altas taxas de participação das massas com tendência facista e a introdução de regimes totalitários no pós-guerra, baseados na participação das massas, ainda que uma participação forçada pela intimidação e pela coerção, realçam a tendência de se relacionar a palavra 'participação' com o conceito de totalitarismo mais do que com o de democracia".

Associando-se a isso a constatação de que a maior parcela da população, em especial as camadas de mais baixo nível socioeconômico, demonstra pouco interesse pela atividade política, tem-se um coquetel que leva ao desenvolvimento de teorias em que há um esvaziamento do significado da democracia no seu sentido original, ou seja, o poder de decisão popular sobre os destinos da sociedade onde vive - o direito de influir nas decisões que dizem respeito à coletividade.

Esse esvaziamento do sentido original da idéia de democracia demonstra bem que, ao contrário do que se possa pensar, democracia e liberalismo não nascem juntos e sua associação deu-se apenas no século XIX, como resultado do processo histórico vivido pela civilização ocidental — berço da idéia de democracia - no decorrer do século XIX e adentrando o século XX.

\section{A fusão entre democracia e liberalismo}

Como foi observado anteriormente, as idéias de democracia e liberalismo não se fundiram a não ser no século $\mathrm{XIX}^{4}{ }^{4} \mathrm{~A}$ apropriação do conceito de democracia pela doutrina liberal deu-se de tal forma que atualmente é difícil pensar o ideal democrático sem levar em conta os valores surgidos com a ideologia liberal no tocante à liberdade individual, à igualdade perante a lei e ao regime representativo.

HOBSBAWN (1996) observa que essa fusão ocorre em um momento em que as pressões das "massas", como os camponeses e a nova e crescente classe trabalhadora indus- 
trial, questionavam a política burguesa. A Revolução de 1848 demonstrava que essas massas numerosas poderiam se levantar contra o Estado burguês, forçando-o à abertura de espaços para a participação política dessas camadas da população, especialmente da crescente parcela dos trabalhadores industriais. Ademais, como observa o autor, o liberalismo, que formava a base da ideologia burguesa, ao defender os ideais de igualdade legal, não tinha justificativa para oporse a essas demandas de participação popular na política.

Afirma o autor que a década de 1850 ainda transcorreu de forma tranquiila para a sociedade burguesa; ${ }^{5}$ porém, a década de 1860 provou que não era mais possível manter esse tipo de política. Duverger elucida este processo ao afirmar que: "nas cinco últimas décadas do século XIX, (...), o liberalismo viu-se desafiado: o seu compromisso extremo com o mercado (...) deixava-o numa situação absolutamente difícil ante as exigências de reformas sociais e políticas que a classe trabalhadora fazia de forma cada vez mais contundente". (DUVERGER apud REZENDE, 1997, p.29)

Esse avanço dos governos representativos na maior parte da Europa e na América do Norte (Estados Unidos) deveu-se, portanto, à forma de hegemonia da burguesia na sociedade ocidental; pois, ao contrário da aristocracia feudal ou do monarca absoluto, a burguesia necessitava angariar o apoio das massas à medida em que seu poder não se fundava em instituições que poderiam, como coloca o autor, "salvaguardála" do voto; ao contrário da anteriormente citada aristocracia feudal, cujo poder era baseado em uma rígida hierarquia estamental. O próprio ideário burguês (embasado na doutrina liberal) tornava essa salvaguarda impraticável, pois defendia a liberdade individual e a igualdade legal de todos os indivíduos $^{6}$ e, portanto, era incompatível com o total afastamento das massas do processo político.

Assim, em um contexto social onde a burguesia não tinha como manter um regime autocrático, tanto pelo crescente movimento de emancipação popular que caracterizou o final da era feudal quanto pela impossibilidade ideológica de manutenção de um regime de tal natureza, a organização de regimes representativos significava uma forma pela qual a burguesia poderia manter a hegemonia na sociedade, conseguindo mobilizar o apoio das camadas não-burguesas através da defesa de ideais gerais de igualdade e liberdade.

O momento histórico possibilitava este movimento, visto que o liberalismo econômico, desenvolvendo-se como doutrina que poderia dar resposta às exigências do desenvolvimento industrial, transbordou a esfera puramente econômica e embasou toda a estrutura ideológica do pensamento burguês, não podendo deixar de ter seus reflexos no pensamento político da época, portanto.

\section{Antecedentes teóricos}

Já no século XVIII tomavam forma várias teorias democráticas em que, na Europa que passava por transformações em direção ao capitalismo e à hegemonia burguesa, centravam suas preocupações na constituição de um tipo de governo não-despótico, debate em meio ao qual ganha relevo a problemática da relação entre democracia e república.
Essa preocupação com o governo não-despótico pode, entretanto, ser já bem observada no final do século XVII, na obra de John Locke. Após a ascensão de Guilherme de Orange ao trono britânico em 1688, com o sucesso da Revolução Gloriosa, Locke retorna à Inglaterra após um longo período de exílio na Holanda, e suas principais obras são publicadas, revelando já uma teorização de base liberal e a preocupação com o governo limitado.

No Segundo tratado sobre o governo, Locke vai justificar a Revolução Gloriosa com base no direito de resistência, partindo do princípio que somente o consentimento ${ }^{7}$ do povo dá legitimidade ao governo e que este tem por função a defesa da propriedade e a proteção contra inimigos internos e externos. Quando o governo atenta contra a propriedade ou viola as leis estabelecidas, este entra em conflito com a sociedade que o constituiu e que tem o direito de resistência à sua tirania. (LOCKE, 1983)

Baseado na livre associação da população em um contrato social, a forma de governo que irá comandar o regime civil deve ser escolhida pela comunidade, através do princípio de maioria, onde os direitos da minoria devem ser respeitados. Cabe também à comunidade determinar o Poder Legislativo, que se constituirá enquanto poder máximo ao qual se subordinam o Poder Executivo e o Federativo.

Assim, para Locke, os fundamentos do governo civil são a preservação dos direitos naturais à vida, à propriedade e à liberdade; e o consentimento da comunidade a esse governo, o que faz deste autor um dos precursores do individualismo liberal.

Montesquieu, por sua vez, já no século XVIII tem como preocupação básica a definição das formas de governo ${ }^{8}$ e sua estabilidade, onde a igualdade e a liberdade ocupam um lugar de destaque, fundamentadas sempre no reconhecimento e respeito às leis. A forma republicana $\mathrm{e}$ democrática era pensada a partir do princípio da igualdade. (cf. ALBUQUERQUE, 1991)

A liberdade, para Montesquieu, era definida e limitada pela lei - onde o abuso do poder era tido como desrespeito às leis, à medida em que tolhia a liberdade - e a tripartição dos poderes garantia o espaço de discussão e de liberdade política.

Ainda no século XVIII, Rousseau também analisaria a problemática da constituição do governo, destacando as questões da liberdade e da igualdade. No Discurso sobre a origem da desigualdade entre os homens e em Do contrato social, Rousseau trata dessas questões a partir da passagem do estado de natureza para o estado civil. (ROUSSEAU, 1978a; 1978b)

Partindo do estado de natureza, onde, para Rousseau, o homem é livre para, com o surgimento da propriedade privada, tornar-se escravo no estado civil, o autor tenta estabelecer as condições necessárias a um pacto social legítimo em que os homens, em troca da perda da liberdade do estado de natureza, ganhassem a liberdade civil. Tal pacto legítimo seria possível mediante um sistema em que prevalecesse a soberania popular e a vontade geral:

"Se separarmos então, do pacto social, o que não é de sua essência, percebemos que ele se reduz aos se- 
guintes termos: 'Cada um de nós põe em comum sua pessoa e todo seu poder sob a suprema direção da vontade geral, e recebemos, enquanto corpo, cada membro como parte indivisível do todo"'. (ROUSSEAU apud NASCIMENTO, 1991, p.220)

Comenta PATEMAN (1992) que na teoria de Rousseau,

"a participação popular é bem mais que um complemento protetor de uma série de arranjos institucionais: ela também provoca um efeito psicológico sobre os que participam, assegurando uma inter-relação contínua entre o funcionamento das instituições e as qualidades e atitudes psicológicas dos indivíduos que interagem dentro deles". (PATEMAN, 1992, p.35)

Para Rousseau, somente o direito limitado de propriedade é compatível com a soberania popular. O autor defende uma sociedade de pequenos proprietários onde houvesse igualdade e independência econômica, configurando uma situação em que "nenhum cidadão fosse rico o bastante para comprar o outro e em que nenhum fosse tão pobre que tivesse que se vender". (idem, p.36)

O sistema político defendido Do contrato social não é, entretanto, uma democracia, pois segundo Rousseau, nunca existiu uma verdadeira democracia. Porém, como nota Rezende, a obra "destacou a necessidade de criação das bases para que o Estado se tornasse o mais democrático possível. A máxima participação do indivíduo no processo político era a condição fundamental para se alcançar este objetivo". (REZENDE, 1997, p.26)

Nota-se, dessa forma, que as concepções liberais e democráticas apresentavam-se, no decorrer do século XVII, separadas. Gruppi ${ }^{9}$ observa que, enquanto as concepções liberais defendiam a correlação entre propriedade privada e liberdade, e, portanto, na aceitação da desigualdade entre os homens, as concepções democráticas pautavam-se pela defesa da igualdade. Tal distinção se torna bem clara ao se fazer uma comparação entre as idéias de Locke ou de Madison ${ }^{10}$ em suas defesas do governo representativo e da propriedade com as de Rousseau, que se baseava no autogoverno e na igualdade econômica. Esse contraste se tornará mais claro a seguir, quando serão abordadas as concepções liberais de democracia.

\section{século XIX e a evolução das idéias liberal-democráticas}

Como já foi colocado anteriormente, o século XIX representa o período histórico onde ocorre a fusão das idéias liberais com as democráticas, resultado do processo histórico de destruição da ordem feudal e consolidação do capitalismo industrial na Europa e na América do Norte. Nesse século começam a se delinear as linhas gerais de uma concepção de democracia (no que tange ao sufrágio universal) que, ao contrário das idéias do século anterior, não a considera incompatível com o direito à propriedade.
Como observa MACPHERSON (1978, p.30),

"os primeiros formuladores da democracia liberal vieram a defendê-la mediante uma cadeia de raciocínios que partia do pressuposto de uma sociedade capitalista de mercado e as leis da economia política clássica. Esses postulados deram-lhes um modelo do homem (como maximizador de utilidades) e um modelo de sociedade (como conjunto de indivíduos com interesses conflitantes). A partir desses modelos, e um princípio ético, deduziram a necessidade de governo, as desejáveis funções do governo e daí o sistema desejável de escolher e autorizar governos".

As teorias democráticas liberais tiveram com Jeremy Benthan e James Mill um importante ponto de partida. Considerado por Macpherson como o fundador da teoria utilitarista, Benthan, partindo dos pressupostos da economia política clássica, constrói sua teoria com base na procura individual da maximização da felicidade, tomada como a quantidade de prazer individual menos a de sofrimento.

Nessa busca individual da felicidade, cada indivíduo deveria contar como um, configurando-se aí seu princípio ético de igualdade. Porém esse princípio ético é restringido quando da discussão sobre a igualdade e a segurança da propriedade privada, pois, de acordo com essa teoria,

"ninguém faria um plano de vida ou empreenderia qualquer tarefa cujo produto não pudesse imediatamente tomar e utilizar. Nem mesmo o simples cultivo da terra seria empreendido se alguém não estivesse seguro de que a colheita seria sua. As leis, portanto, devem garantir a propriedade individual. E dado que os homens diferem entre si em capacidade e energia, alguns obterão mais propriedade que outros. Qualquer pretensão da lei em reduzi-las a igualdade destruiria o incentivo à produtividade. Daí, na alternativa entre igualdade e segurança, a lei não pode ter hesitação absolutamente alguma: 'a igualdade deve ceder’”. (MACPHERSON, 1978, p.36)

REZENDE (1997) afirma que a maior contribuição de Benthan para a teoria democrática foi a discussão sobre o Estado e o sistema de governo, onde o objetivo do sistema democrático seria a proteção dos cidadãos baseado num governo representativo e em franquias democráticas.

James Mill, assim como Benthan, concentrou sua atenção nos "arranjos institucionais" necessários à manutenção de um governo voltado para o interesse universal, baseando sua teoria num sistema de franquia universal que, porém, mantinha a exclusão política de grande parte dos indivíduos, como demonstra MACPHERSON (1978, p.42-43):

"Mas não se pode afirmar que James Mill fosse um entusiasta da democracia, tanto quanto o fora Benthan. Pois no mesmo artigo sobre Governo em que defendeu a franquia universal, James Mill valeu-se de considerável habilidade ao indagar se qualquer franquia mais estreita poderia dar a mesma segurança para o 
interesse de cada cidadão como o daria a franquia universal, e argumentava que seria prudente excluir todas as mulheres, todos os homens menores de 40 anos, e os mais pobres, que constituíam um terço dos homens de mais de 40 ".

Já em meados do século XIX, John Stuart Mill avança na discussão da democracia liberal, revolucionando o pensamento liberal democrático daquele século, como comenta BALBACHEVSKY (1991, p.195):

"Com Mill, o liberalismo despe-se de seu ranço conservador, defensor do voto censitário e do e da cidadania restrita, para incorporar em sua agenda todo um elenco de reformas que vão desde o voto universal até a emancipação da mulher. Na obra de Mill podemos acompanhar um esforço articulado e coerente para enquadrar e responder as demandas do movimento operário inglês".

Assim, MILL (1964) coloca em debate a necessidade de desenvolver um "adiantamento mental geral" da sociedade com vistas a alcançar o aperfeiçoamento do sistema político, tendo em vista sua posição em defesa de ampla participação social ${ }^{11}$ no processo político:

"é preciso ter presente ao espírito que o mecanismo político é incapaz de agir por si. Sendo, de início, feito pelos homens, estes terão de fazê-lo funcionar, até mesmo por homens vulgares. Torna-se-lhe necessária não a simples aquiescência, mas a participação ativa que terá de ajustar-se às aptidões e qualidades de tais homens, conforme disponíveis". (MILL, 1964, p.7)

O primeiro elemento de um bom governo é, para ele, a virtude e a inteligência dos indivíduos da comunidade; onde estes não se preocupem apenas com os interesses particulares. Assim, o principal papel do bom governo é a promoção dessa virtude e inteligência, com vistas à constituição de uma sociedade equilibrada. E a forma de governo idealmente melhor para Mill é a forma representativa calcada em dois princípios:

"O primeiro consiste em que os direitos e interesses de todos ou de cada um só se encontram garantidos de desconsideração quando o interessado é capaz de sustentá-los e está habitualmente disposto a fazê-lo. $O$ segundo reza que a prosperidade geral atinge maior elevação e difunde-se mais amplamente na proporção do volume e variedade das energias pessoais interessadas em promovê-la". (idem, p.40)

Como é impossível, porém, que todos participem do governo diretamente, Mill defende então as formas representativas de governo.

Para o autor, haveria somente uma forma de capacitar os indivíduos a participar do governo representativo, como observa PATEMAN (1992), que é a participação em nível local, onde os indivíduos "aprenderiam" democracia.
MILL (1964) observa, porém, que o governo representativo tem seus perigos, sendo o maior deles - como em qualquer tipo de governo - a prevalência do interesse dos que ocupam o poder, que resultaria numa legislação classista em benefício da classe dominante. Por isso, ele se preocupa em propor formas de evitar a imposição da maioria sobre uma minoria, através da dotação de dispositivos ao sistema político que garantissem a participação dessas minorias, tais como o voto proporcional e o voto plural. ${ }^{12}$

A preocupação com o desrespeito às minorias, e por extensão ao cerceamento da liberdade, encontrou, porém, seu grande representante em Alexis de Tocqueville. Em sua principal obra, A democracia na América (cf. QUIRINO, 1991), Tocqueville defende a idéia de que o principal fundamento da democracia é a liberdade, tentando encontrar uma forma de coexistência harmônica entre a igualdade (considerada por ele um processo inexorável) e a manutenção da liberdade.

Tocqueville vê a democracia ${ }^{13}$ como um processo universal, que se conduziria de acordo com as condições encontradas em cada nação. Afirma, no entanto, que todos os países caminharão para um processo de igualdade ${ }^{14}$ cada vez maior, em que a ação política do povo terá papel primordial na construção da democracia.

Assim, sendo o desenvolvimento do processo igualitário irrefreável para Tocqueville, ele dedica sua obra ao estudo dos perigos à liberdade inerentes a esse processo. Tocqueville, dentro dessa abordagem, detecta dois grandes perigos à manutenção da liberdade: o aparecimento de uma sociedade de massa que desembocaria em uma ditadura da maioria, e o surgimento de um Estado autoritário.

Como resume LIPSET (1967, p.27),

"O interesse de Tocqueville por um sistema político pluralista resultou de sua interpretação das tendências evolutivas da sociedade moderna. Industrialização, burocratização e nacionalismo, que estavam levando as classes inferiores para o domínio da política, estavam igualmente minando os alicerces dos menores centros locais de autoridade, concentrando o poder no Estado-leviatã. Tocqueville temia que o conflito social desaparecesse por causa da existência, neste caso, de um único centro de poder - o Estado - a que nenhum outro grupo teria força bastante para opor-se. Deixaria de haver competição política porque não existiriam mais bases sociais para sustentála. Receou também que o consenso fosse do mesmo modo solapado na sociedade de massas. Ao indivíduo pulverizado, entregue a si próprio, sem filiação numa unidade social, faltaria o interesse suficiente para participar na política ou até para simplesmente aceitar o regime. A política seria não só vazia de finalidade como de significado".

Tocqueville também investe contra o individualismo típico da sociedade industrial que se desenvolvia a passos largos, pregando uma certa moralidade política, onde a atividade política dos cidadãos e a manutenção de instituições que desenvolvessem a descentralização administrativa e a 
associação destes mesmos cidadãos, bem como a existência de leis que garantissem a manutenção das liberdades fundamentais, podem dificultar o surgimento do Estado autoritário ou de uma sociedade massificada.

Configura-se, assim, o panorama do surgimento das teorias liberal-democráticas no século XIX, as quais tiveram profundos reflexos em seu posterior desenvolvimento no século XX, onde, apesar das transformações pelas quais passaram, pode-se notar uma grande dívida para com os pioneiros teóricos do século anterior.

\section{O desenvolvimento das teorias liberal-democráticas no século XX}

O processo que se configurava na sociedade capitalista industrial que adentra o século XX teve profunda influência nas teorias políticas. O desenvolvimento de uma sociedade cada vez mais burocratizada, amplamente estudado, por Weber, teve profundo impacto nessas teorias, chegando a ser colocada em dúvida por alguns teóricos a possibilidade de desenvolvimento de uma democracia nos moldes como era pensado. PATEMAN (1992) cita Mosca e Michels como os mais influentes nessa linha de pensamento. Mosca, adepto de uma teoria elitista de governo, ${ }^{15}$ defendia a necessidade de uma elite no poder em uma sociedade burocratizada; enquanto Michels, partindo do estudo dos partidos socialdemocratas alemães, desenvolveu a "lei de ferro da oligarquia". ${ }^{16}$

Dentro da linha liberal-democrática, porém, a teoria mais influente do século XX foi, sem dúvida nenhuma, a desenvolvida por Schumpeter. Como coloca BOTTOMORE (1984, p.12), "ele formula uma definição econômica de democracia, concebida como um arranjo institucional semelhante ao mercado, em que vários grupos e indivíduos equivalentes a empresas e empresários - competem entre si pelos votos dos eleitores".

Partindo de uma visão pretensamente empírica do problema da constituição do "método político", 17 SCHUMPETER (1984) refuta as teorias políticas do século XVIII que se assentavam em torno da idéia de bem comum e "vontade do povo", estabelecendo uma teoria em que o "método democrático" é visto como um "acordo institucional para se chegar a decisões políticas em que os indivíduos adquirem o poder de decisão através de uma luta competitiva pelos votos da população."(SCHUMPETER, 1984, p.336)

Essa visão mercadológica do processo democrático reduz a participação da população no método democrático à função de determinação do governo (através de eleição direta ou indireta com voto livre), assim como o direito de desapossá-lo, retirando-lhe, porém, a capacidade de definição racional de seus objetivos e da escolha de seus representantes, pois, para Schumpeter, "a vontade do povo é o produto e não o motor do processo político" (idem, p.329); ou seja, para ele a democracia é uma disputa competitiva ${ }^{18}$ entre elites pelos votos da população em que, sendo a maioria da população pouco informada e pouco interessada nas questões específicas do campo político, no qual o "cidadão típico cai num nível mais baixo de desempenho mental" (idem, p.328), e em que suas decisões baseiam-se na falta de senso racional e na afetividade, os variados grupos com interesses políticos ou econômicos podem influenciar muito amplamente e até determinar a vontade popular.

Com essa visão, Schumpeter retira do processo democrático toda idéia de uma atuação em torno de meios e fins, o que esvazia a idéia original de "governo do povo" ou objetivando o "bem comum" ou o "governo da maioria" para um simples método de escolha de governo, em que sua participação consiste, em última instância e segundo suas próprias palavras, na "aceitação de um líder ou grupo de líderes"(idem, p.340) e onde o controle que o eleitorado exerce sobre seus líderes se dá apenas no processo eleitoral e na possibilidade de recusa à reeleição de uma elite.

Outro pensador de grande importância no século XX e que vê a democracia como uma disputa de líderes é Robert Dahl. Partindo das críticas às teorias democráticas madisoniana e populista, DAHL (1989) constrói seu modelo de democracia poliárquica, também através de uma construção empírica, onde ele se põe à busca de princípios limitadores que garantiriam a igualdade política e a soberania popular.

A democracia poliárquica seria composta de dois estágios - o eleitoral e o pós-eleitoral — em que haveria uma disputa competitiva entre seus componentes em um processo onde é fundamental o consenso em torno das oito condições que determinam e conduzem o processo de escolha das lideranças nos estágios eleitoral e pós-eleitoral. No estágio eleitoral, resumidamente, exige-se a participação de todos os membros de uma organização através do voto, onde haveria igualdade política, todos possuiriam as mesmas informações a respeito das alternativas em disputa e garantida a vitória da opção mais votada. No estágio pós-eleitoral, exige-se a prevalência do grupo vencedor sobre os outros e o respeito às suas determinações.

As poliarquias incluem, segundo Dahl, vários tipos de organizações "democráticas", tais como governos de Estados, cidades, sindicatos e associações, que concorrem junto com a Igreja, a famúlia, a escola, a imprensa, etc. para o treinamento social dos seus componentes da qual a democracia poliárquica é dependente, visto que o consenso em torno das regras que determinam a poliarquia é decorrência da extensão desse treinamento social.

$\mathrm{O}$ autor aborda também o problema da apatia política das massas, colocando o problema da decisão entre uma minoria intensamente participante e uma maioria apática, onde defende a existência de uma regra que estabeleça que a preferência mais intensa deveria ganhar. Para o autor isso não afetaria o caráter democrático do sistema de decisão, visto que, embora a maioria raramente escolha em questões de política específica, o processo de decisão de minoria que se aplica nesses casos está na maioria do tempo dentro das regras do consenso que regem a poliarquia.

Como observa PATEMAN (1992, p.18), na teoria de Dahl, "uma porcentagem relativamente pequena de indivíduos, em qualquer forma de organização social, aproveitará as oportunidades de tomada de decisão. E, portanto, o 'controle' depende do outro lado do processo eleitoral, da competição entre os líderes pelos votos da população". 
Configura-se mais uma vez, portanto, a disputa entre líderes, embora os não-líderes exerçam algum controle sobre eles através da possibilidade de mudança de opinião e apoio e, conseqüentemente, de apoio a outro grupo que esteja disputando a liderança. DAHL (1989) constata, porém, os perigos decorrentes da participação do homem comum no processo, que se concentram na idéia de que, possuindo esses grupos um menor índice de atividade política e uma maior frequiência de personalidades autoritárias, o aumento da participação eleitoral desses grupos poderia levar a uma diminuição em torno do consenso necessário à operação da democracia poliárquica.

SARTORI (1965) também desenvolve sua teoria democrática sobre a idéia de um governo de elites em competição. Contrapondo sempre a idéia de uma democracia ideal e de uma democracia real, o autor defende a idéia de que a democracia real é na verdade uma democracia governada, em que "a influência da maioria é assegurada por minorias eletivas e concorrentes às quais ela é confiada" (SARTORI, 1965, p.141) e onde a democracia, apesar de ser, na verdade, uma política de elites, é moldada pela idéia valorativa da democracia governante, ou seja, de soberania popular, onde estas "dependem da lei da maioria (...), dos mecanismos eletivos e da transmissão representativa do poder". (idem, p.39)

A participação popular, no entanto, na teoria de Sartori, restringe-se apenas à participação no processo eleitoral, que, através de pressão e controle, influencia a atividade política; sem, no entanto, governar de fato. E ainda assim, mesmo em eleições livres, Sartori vê o perigo da manipulação da opinião pública — "uma opinião que o povo de modo algum formou por si mesmo" (idem p.89) - pelos meios de comunicação de massa, revelando uma certa desconfiança em relação à participação popular nos destinos do processo político.

Sartori também aborda o problema da apatia política das massas, negando que ela seja resultado de condições sociais, como o analfabetismo, mas, sim, simples desinteresse pela atividade política. Ele defende que as únicas questões que um indivíduo pode compreender são aquelas em que este tem experiência pessoal ou que formulou por si próprio, o que não acontece em relação às questões políticas. Dessa forma, sendo a apatia política apenas e tão somente devido à falta de interesse, a atividade política deve ser exercida pelos grupos politicamente ativos: "a democracia é o poder das minorias democráticas, que o significado da palavra 'democrática' é o de que o recrutamento dessas minorias deve ser franco, e que elas devem competir de acordo com as regras de um sistema multipartidário". (idem, p.106) $\mathrm{O}$ autor dá, dessa maneira, grande importância à existência de uma oposição como fator de garantia da soberania popular dentro das regras do princípio majoritário.

LIPSET (1967) também enfatiza o processo eleitoral e a existência de conflitos direcionados ao sistema eleitoral para a manutenção de uma democracia estável. Esses conflitos representam a luta por posições dominantes no sistema político que são canalizados pela via pacífica do jogo democrático.

Assim, ele conceitua a democracia nas sociedades complexas como: "um sistema político que fornece oportu- nidades constitucionais regulares para a mudança dos funcionários governantes, e um mecanismo social que permite a uma parte - a maior possível — da população influir nas principais decisões mediante a sua escolha entre os contendores para cargos públicos". (LIPSET, 1967, p.45)

Na operação desse sistema político, os partidos exercem papel fundamental, ${ }^{19}$ pois é através deles que se dará a luta competitiva e pacífica pelo poder. Em uma democracia estável, a configuração dos partidos deve corresponder às divisões sociais básicas da sociedade como um todo, incluindo elementos dos vários segmentos da população.

Lipset faz também uma correlação entre o nível de desenvolvimento econômico de uma nação e a estabilidade da democracia. Segundo ele, quanto mais desenvolvida economicamente uma nação, maior a probabilidade de sustentar uma democracia estável, à medida em que esta se liga a fatores como educação, religião e renda. A apatia política também tem relação com o nível de desenvolvimento econômico, pois, quanto mais desenvolvida economicamente a nação e quanto menores são os conflitos sociais importantes, mais apática é a população.

Porém, a estabilidade da democracia não depende somente do nível de desenvolvimento econômico da nação, mas também da eficácia do governo no atendimento das reivindicações básicas da sociedade e da legitimidade do sistema, no sentido de que o governo consegue manter a crença de que as instituições vigentes são as mais adequadas.

Lipset, no entanto, não considera a democracia apenas como um sistema político no qual grupos de interesse defendem suas propostas, mas sim a procura de realização de uma "boa sociedade", ou a própria "boa sociedade" em funcionamento.

\section{CONSIDERAÇÕES FINAIS}

Através desse breve levantamento sobre o desenvolvimento do pensamento democrático liberal, pode-se depreender algumas características gerais muito úteis.

Apesar das várias diferenças entre os diversos teóricos, pode-se dizer que uma característica geral das teorias liberal-democráticas, em especial nos teóricos do século XIX, era a preocupação com a preservação da liberdade individual frente ao crescente poder do Estado que se tornava cada vez mais burocratizado e poderoso dentro da sociedade industrial.

Essa preocupação com a limitação do poder do Estado e o respeito às minorias, enquanto defesa da liberdade individual, evolui no século $\mathrm{XX}$ para teorias que se concentram em um sistema político autônomo em que a participação da população se reduz ao ato do voto ou então se torna uma disputa entre elites que competem entre si em um jogo político que canaliza os conflitos para este sistema político.

Porém, como coloca TOURAINE (1996), a democracia não é somente um conjunto de garantias institucionais. Essa visão elimina da idéia de democracia seu significado essencial, que é a luta de indivíduos que possuem uma carga de cultura e experiência pessoal pela igualdade e pela liber- 
dade, bem como elimina a idéia do fim em si da democracia, que é a autodeterminação da sociedade. Essa idéia tem sido recuperada atualmente nos estudos da nova cidadania, que têm ganhado grande espaço nos meios acadêmicos, levando à formulação de uma nova noção de democracia e de cidadania, alargando as fronteiras da esfera política em direção a uma sociedade civil complexa e multifacetada. Porém, os conceitos liberais de democracia continuam ainda bastante difundidos.

Um outro efeito paradoxal das teorias democráticas liberais é esta certa desconfiança em relação à participação popular para a qual PATEMAN (1992) chama a atenção. Se a democracia em sua acepção literal é o governo do povo, é um contra-senso o temor de que a participação popular venha a ameaçar algo que, sem sua ativa participação, perde totalmente o significado.

A concentração da atenção no sistema político também tira de debate a questão da igualdade econômica e social, que é relegada a um segundo plano, ou concebida como uma fase posterior e um produto mesmo do desenvolvimento da democracia, como se observa em MARSHALL ${ }^{20}$ (1967), mascarando, por vezes, uma situação de extrema desigualdade social e econômica pela existência de um sistema político legalmente livre.

Assim, em sua busca pela racionalidade e pela institucionalização do jogo político, os teóricos liberais acabaram por transformar o conceito de democracia em uma construção teórica que perdeu de vista os fins últimos a que deveriam ser aplicadas e, portanto, sua essência.

\section{NOTAS}

Esses conceitos são abordados com maior propriedade e aprofundamento mais adiante, porém, para o momento, esta conceituação ampla pode servir como um parâmetro de orientação útil na introdução do assunto em desenvolvimento.

2 Como observa Marcílio Marques Moreira, a ênfase no papel do príncipe enquanto líder acentua a valorização do indivíduo característica do Renascimento, do qual o pensamento de Maquiavel é produto. A valorização do indivíduo desempenhará mais tarde um papel de grande importância no desenvolvimento da ideologia liberal; porém, nesse contexto, não invalida a idéia de uma concepção que dá ênfase ao papel do Estado em relação à sociedade. (MOREIRA, 1984)

3 Hobbes defende a idéia de igualdade das faculdades de corpo e espírito entre todos os homens, o que demonstra já uma visão individualista do homem, mas o papel determinante que reserva ao Estado em sua teoria, enquanto elemento-base que possibilita a convivência social, justifica esta sua classificação. (HOBBES, 1979)

4 Apesar de ser possível detectar idéias que poderiam ser equiparadas às teorias democráticas liberais já no século XVII, como em Jefferson e em idéias associadas ao puritanismo, Macpherson observa que a tradição política ocidental até os séculos XVIII e XIX não se ocupava do nãodemocrático ou do antidemocrático - a participação popular na política era considerada incompatível com a sociedade liberal. Já HOBSBAWN (1996) e DUVERGER (cf. REZENDE, 1997) concentram suas observações a respeito da democracia liberal na questão da possibilidade ou impossibilidade de manter regimes que excluíssem as massas do processo político, o que se tornou impossível no século XIX.

5 Exceto na França onde a ocorrência de três revoluções tornava impossível a simples exclusão das massas do processo político. Como observa o autor, "elas deveriam então ser dirigidas". (HOBSBAWN, 1996, p.149)

6 Como coloca Weber, o tipo-ideal que caracteriza a dominação tradicional (a qual é possível identificar com o tipo de dominação feudal) fundamen- ta-se em uma legitimidade baseada "na crença na santidade de ordens e poderes senhoriais tradicionais (...). Determina-se o senhor (ou os vários senhores) em virtude de regras tradicionais. A ele se obedece em virtude da dignidade pessoal que lhe atribui a tradição". (WEBER, 1991, p.148)

7 Locke desenvolve uma teoria de caráter contratualista, assim como Hobbes, porém, seu conceito de estado de natureza difere em muito deste último. Para Locke, o estado de natureza era um estado de relativa paz, onde os homens já eram dotados de razão e possuíam a propriedade, entendida como a vida, a liberdade e os bens, tida enquanto direito natural. Neste ambiente de relativa paz havia, porém, inconvenientes, como a violação da propriedade; e é por esses inconvenientes que os homens fazem livremente o contrato social que institui o governo civil.

8 Montesquieu define três formas de governo, segundo sua natureza: a monarquia, a república e o despotismo, dos quais a república, baseada no princípio da virtude, pode levar à consideração do interesse público sobre os particulares.

9 Citado por REZENDE (1997, p.26).

${ }^{10}$ Segundo DAHL (1989, p.16), Madison parte, para construção de sua teoria, da hipótese de que "Na ausência de controles externos, qualquer dado indivíduo, ou grupo de indivíduos, tiranizará os demais"; o que coloca a necessidade de aplicação de controles, na forma de penalidades e recompensas e na separação dos poderes, que evitariam a tirania de uns sobre outros. Porém, a forma de governo sobre a qual discorre Madison é a de governo representativo e não a democracia pura. Esta última era considerada como pequenas comunidades que se autogovernavam; enquanto que o governo representativo abrangeria um maior número de cidadãos que delegariam seus poderes a poucos representantes.

${ }^{11}$ Mill observa, porém, alguns casos em que deve haver a exclusão do direito ao voto por motivos positivos, que se aplicariam às pessoas analfabetas, aos que não pagam impostos e dos indigentes.

${ }^{12} \mathrm{O}$ sistema de voto plural dá pesos diferentes ao voto, dependendo do grupo. $\mathrm{O}$ argumento utilizado por Mill para a adoção desse sistema é que, havendo naturalmente uma polarização entre os interesses das classes proprietárias e dos trabalhadores, deveria haver um terceiro grupo que equilibraria o sistema devido a suas condições específicas, que seria a elite cultural.

${ }^{13}$ Caracterizada como um processo de constante aumento da igualdade de condições de toda a humanidade

${ }^{14} \mathrm{O}$ conceito de igualdade de Tocqueville concentra-se nas igualdades cultural e política como elementos que tornariam o povo mais homogêneo, não apenas na igualdade econômica.

${ }^{15}$ Recomendamos a leitura do artigo "Uma contribuição à crítica da teoria das elites", do professor Décio Saes, publicado na Revista de Sociologia e Política n.3, de 1994, que apresenta uma contundente análise crítica sobre a teoria das elites.

${ }^{16}$ A "lei de ferro da oligarquia" de Michels parte de uma concepção onde a necessidade de organização leva à transformação de toda estrutura partidária em uma organização oligárquica.

${ }^{17}$ Conceituado como "o método que uma nação usa para chegar a decisões". (SCHUMPETER, 1984, p.305)

${ }^{18} \mathrm{E}$ isso pressupõe a existência de liberdades civis que garantiriam o voto livre da população.

${ }^{19}$ Lipset considera que nas democracias modernas, o conflito entre os diferentes grupos de interesse é expresso pelos partidos políticos, que representam "uma tradução democrática da luta de classes". (LIPSET, 1967, p.231)

${ }^{20}$ Nesta obra Marshall aborda o desenvolvimento da cidadania dividindoo em três partes: a cidadania civil, a cidadania política e a cidadania social, enquadrando-os dentro de uma visão evolutiva e ascendente de desenvolvimento ao longo da história. Ver especialmente o capítulo III "Cidadania e classe social".

\section{REFERÊNCIAS BIBLIOGRÁFICAS}

ALBUQUERQUE, J.A.G. "Montesquieu: sociedade e poder". In: WEFFORT, F.C. (org.). Os clássicos da política. v. 1. São Paulo: Ática, 1991. p.111-120.

BALBACHEVSKY, E. "Stuart Mill: liberdade e representação". In: WEFFORT, F.C. (org.). Os clássicos da política. v. 2. São Paulo: Ática, 
1991, p.189-199.

BOTTOMORE, T. "Introdução". In: SCHUMPETER, J.A. Capitalismo, socialismo e democracia. Rio de Janeiro: Zahar, 1984.

DAHL, Robert. Um prefácio à teoria democrática. Rio de Janeiro: Zahar, 1989.

HOBBES, T. O Leviatã ou Matéria, forma e poder de um Estado eclesiástico e civil. São Paulo: Abril Cultural, 1979. (Col. Os Pensadores)

HOBSBAWN, Eric J. "As forças da democracia". In: A era do capital. Rio de Janeiro: Paz e Terra, 1996. p.147-170.

LIPSET, S.M. O homem político. Rio de Janeiro: Zahar, 1967.

LOCKE, J. Segundo tratado sobre o governo. São Paulo: Abril Cultural, 1983. (Col. Os Pensadores)

MACPHERSON, C.B. A democracia liberal. Rio de Janeiro: Zahar, 1978.

MARSHALL, T.H. Cidadania, classe social e status. Rio de Janeiro: Zahar, 1967.

MILL, John S. Governo representativo. São Paulo: Ibrasa, 1964.

MOREIRA, Marcílio M. "O pensamento político de Maquiavel". In: Curso de introdução à ciência política - Estudo de caso: O Príncipe Maquiavel. Brasília: Ed. Unb, 1984.

NASCIMENTO, M.M. do. "Rousseau: da servidão à liberdade". In: WEFFORT, F.C. (org.). Os clássicos da política. v. 1. São Paulo: Ática, 1991. p.187-200.

PATEMAN, C. Participação e teoria democrática. Rio de Janeiro: Paz e Terra, 1992.

QUIRINO, C.G. "Tocqueville: sobre a liberdade e a igualdade". In: WEFFORT, F.C. (org.). Os clássicos da política. v. 2. São Paulo: Ática, 1991. p.149-160.

REZENDE, Maria José de. "A liberdade e a igualdade nas teorias da democracia nos séculos XVIII e XIX". Revista Mediações, Londrina, v.2, n.1, p. 25-33, jan./jun. 1997.

ROUSSEAU, J.J. Discurso sobre a origem e os fundamentos da desigualdade entre os homens. São Paulo: Abril Cultural, 1978a. p.215-310 (Col. Os Pensadores)

Do contrato social. São Paulo: Abril Cultural, 1978b. p.15-145 (Col. Os Pensadores)

SAES, Décio. "Uma contribuição à crítica da teoria das elites". Revista de Sociologia e Política, n.3, p.7-19, 1994.

SARTORI, G. Teoria democrática. Rio de Janeiro: Fundo de Cultura, 1965.

SCHUMPETER, J.A. Capitalismo, socialismo e democracia. Rio de Janeiro: Zahar, 1984.

TOURAINE, A. O que é democracia?. Petrópolis: Vozes, 1996.

WEBER, M. Economia e sociedade. Brasília: Ed. UnB, 1991. 